\title{
The Characteristics of Mosque Architecture Based on Public Preferences in Malang City
}

\author{
W Astrini ${ }^{1}$, E B Kurniawan ${ }^{2}$, M Abdillah $^{1}$
}

Received: 14 September 2019

Accepted: 31 January 2020

\begin{abstract}
Mosque is an architectural work and public facility that serves as a worship place for Muslims. Mosque architectural elements include domes (roofs), mihrab, minaret, arch, and ornaments. Mosque architecture comprises of various elements, which adapt to the local culture where the mosque is located. As such, its presence also bears some impacts on the appearance of urban architecture. Malang city as one of the major cities in East Java has numerous rapidly developing mosque architectures, including Jami' Great Mosque of Malang, Sabilillah Mosque, Nurul Muttaqin Mosque, Ahmad Yani Mosque, and Manarul Huda Mosque. The meaning of architectural work is also closely related to the perception of humans who observe it. The public preference for the architectural characteristics of mosques in Malang city is a manifestation of architectural work. Conjoined analysis is employed as method operative to analyze public preference. This study aims to find out the architectural characteristics of mosques in Malang city according to public preferences. The findings can serve as a recommendation for the development of mosque architectural designs in Malang city, especially those possessing locality values. The architectural characteristics of mosques in Malang city which are driven by the public preferences ranging from the highest to the lowest, which is why mosques generally have calligraphy ornaments, circular arch, pentagon-shaped minaret, Indo-Persian dome, and two-minaret design.
\end{abstract}

Keywords: Mosque architectural elements, public preferences .

\section{INTRODUCTION}

The presence of mosque architectures in each city is influential to portray characteristics or identity for the city architecture. Mosques cannot be separated from Muslim communities as well as their existence, making it more than simply being a place of worship. It is not merely a symbol of Muslims in the area. In addition to its function, mosque architectural elements develop as the teachings of Islam spread to various regions. The architectural elements consist of dome (roof), mihrab, minaret, arch, and ornaments. Mosque architecture often borrows the decorative elements of the previous structures. The process of lending and borrowing from this form of culture is evident as long as it does not interfere with the principles of Islamic faith (Fanani, 2009). Therefore, the work of Islamic architecture in the form of a mosque is laden with universality and characteristics of each in various places, which can be called opportunity. The elements of universality in mosques are formed along with the spread of Islamic teachings. Elements such as dome, arch shape, minaret, and pulpit are present as supporting facilities standardized as markers (Fanani, 2009). These markers unite the architectural patterns of mosques in various regions. The elements of mosque architecture can also be distinguished as the characteristics of each region. This shows that the opportunity remains to be valued in the architectural appearance of the mosque.

\footnotetext{
${ }^{1}$ Architecture Department of Faculty of Engineering, Universits Brawijaya

${ }^{2}$ Regional and Urban Planning Department of Engineering Faculty, Universitas Brawijaya
}

Korespondensi: wulanastrini@ub.ac.id 
Fanani (2009) classified the types of mosque dome into a Persian dome (a top shape), an Ottoman dome (resembling mushroom), and an Indo-Persian dome (resembling onion). The next architectural element is the minaret serving to echo the call to prayer. Minaret is a symbol of reinforcement of the presence of Islam in a region (Grabar, 1973 in Sumalyo, 2000). The shape of the minaret that rises upwards is likened to a vertical stroke in Arabic script in the city skyline. The height above the building makes the minaret on the average as a symbol of the presence of God Almighty or macro scale in human life (Ardalan and Bachtiar, 1973 in Sumalyo, 2000). Many mosques only have one minaret, but many also use compound minarets. Mosque also has architectural elements in the form of arch, the curve structure used for openings such as windows, doors and so on Wardhono (2009). Arch functions to support vertical loads with axial pressure. Ornaments or decorations in mosque architecture according to Wardhono (2009) are not in the form of figurative forms which are prohibited in Islam. The decoration fills parts of construction, walls, columns, beams, and other architectural elements. The types of ornament can be in the form of floral, geometry, and calligraphy (Fanani, 2009).

The development of mosque architecture in Indonesia has experienced very rapid development, and this condition has also occurred in Malang as one of the big cities in East Java. Five mosques in Malang city, Jami' Great Mosque of Malang, Sabilillah Mosque, Nurul Muttaqin Mosque, Ahmad Yani Mosque, and Manarul Huda Mosque, have a variety of architectural elements adorning them. Jami' Great Mosque is one of the oldest mosques in Malang city and has been a reference for the surrounding mosques. According to A'yun, (2015), this mosque experienced three changes to the typology of its facade. At the beginning of its construction, the mosque had a Javanese style with features characterizing those in the archipelago. These characteristics included tajug roofing or overlapping. Manarul Huda Mosque and Nurul Muttaqin Mosque were built before the independence period (simas.kemenag.id) and both had the initial form of a roof in the form of a tajug roof. However, now they have been changed to a dome roof originating from the Middle East. Sabilillah Mosque and Ahmad Yani Mosque were built in the post-independence period (around the 60's), where at the beginning of the construction the two mosques had been constructed with dome roof. The minarets of each mosque were also different. Malang's Jami' Mosque had an octagonal minaret consisting of two pieces. Nurul Muttaqin Mosque and Manarul Huda Mosque have single octagonal minaret. Sabilillah Mosque has a hexagonal minaret, while Ahmad Yani Mosque has a pentagonal minaret. The design development of the five mosques previously presented shows the diversity of architectural elements of the mosques in Malang city.

According to Fanani (2009), an architectural work cannot be separated from the social circumstances around which the mosques are constructed. This shows that the meaning of the architecture work is also closely related to the perception of humans who observe it. In perceiving architectural objects, often architecture is formed by human perception (Laurens, 2004). Likewise, the public perception of mosque architecture can scaffold their preferences towards the architectural characteristics of mosques. Preference is a product of perception. Preference is part of responsive meaning. According to Laurens (2004), responsive meaning is a reaction that will emerge (emotions, feelings, evaluations, perceptions) to the representation he sees. Mosque architecture in Malang City, with a variety of facade-shaped architectural elements have the potential to investigation in revealing public preference for architectural characteristics through its architectural elements. This can affect the physical shape of the mosque in the future.

\section{RESEARCH METHOD}

This research was a quantitative study using conjoined analysis (SPSS 20). Conjoint analysis aims to find out the perceptions of a person towards an object consisting of one or many parts (Santoso, 2015). In this study, conjoint analysis aimed to determine the desired 
architectural characteristics of Malang city or the preferences of the community for the development of architectural designs of mosques in the city, especially in the future. The object of the research is the facade of selected mosques in Malang, Jami'

Great Mosque of Malang, Sabilillah Mosque, Nurul Muttaqin Mosque, Ahmad Yani Mosque, and Manarul Huda Mosque.

The primary data collection was conducted through mosque facade observation to identify the religious elements of the mosque architecture which shapes it and questionnaire distribution to the respondents (Malang city community). The respondents of this study are accounted to 90 people divided into 3 categories, Academia and practitioners in the field of architecture, Islamic religious leaders \& mosque takmirs; and The general public: Architectural pilgrims and students. Research variables are described in the following table 1.

Table 1. Research Variables \& Sub-Variables

\begin{tabular}{ll}
\hline Variables & Sub-Variables (Attributes) \\
\hline Dome & Dome style \\
Minaret & Minaret shape \\
Arch & Arch shape \\
Ornament & Types of ornament \\
\hline
\end{tabular}

\section{RESULT AND DISCUSSION}

The initial stage of this research was to identify the architectural elements of mosques in Malang city. Five observed mosques in the city are those adorned with architectural elements, particularly focusing on façade.

\section{Jami' Grand Mosque of Malang}

Jami' Great Mosque 'Malang is one of the oldest mosques in the city, located at Merdeka Barat 3 Street, Malang. The mosque, established in 1875, is located in the west of Malang city square. This arrangement has been common setting of large mosques in other cities on Java Island where the mosques are located near the town square. The architectural elements which make up the architecture of the Jami' Grand Mosque of Malang are described in the following Figure 1 and 2.
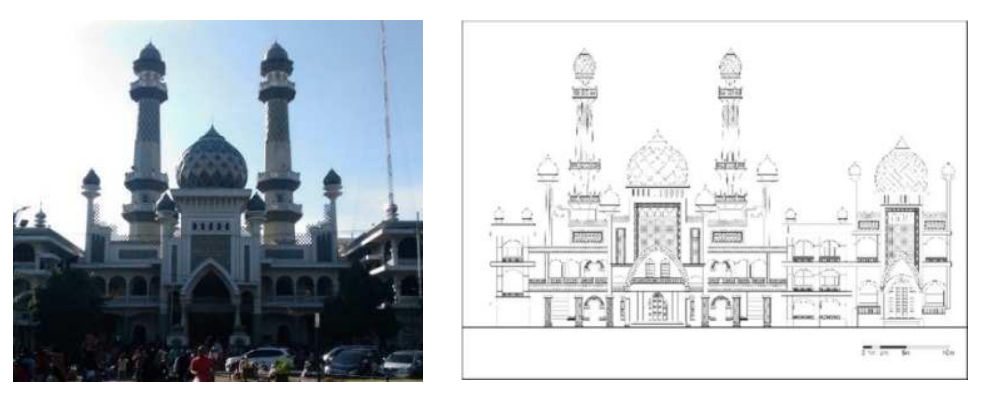

Figure 1. Photos and Façade Pictures of Jami' Great Mosque of Malang

\section{Sabilillah Mosque}

Sabilillah Mosque, located at Ahmad Yani 15 Street in Malang, is included in the typology of large mosque, which is a mosque at the sub-district level, Blimbing sub-district. This mosque was established in 1974 and applied the concept of the monument mosque, 
which represents the date of Indonesian independence (August 17, 1945). The concept application is indicated by the number of pillars around the mosque's porch, including 17 pillars and the ceiling height reached 8 meters. In addition, the number of arches on each side of the building is 8 pieces. The independence year of 1945 is represented by 1 minaret, 9 pillars supporting the dome, and the width and the height of the mosque reaching 45 -meter minaret. The architectural elements which make up the architecture of the Sabilillah Mosque are are described in the following Figure 3 and 4.

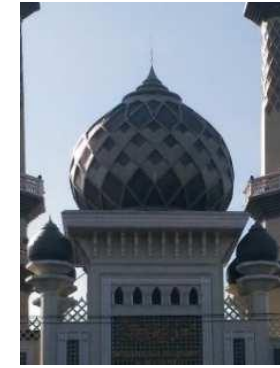

Indo-Persian dome (resembling onion) \& geometrical ornaments

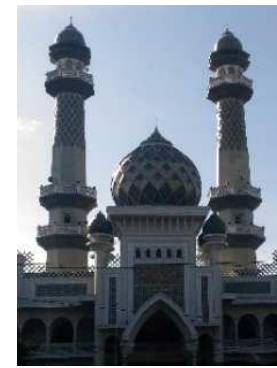

Double octagonal minarets
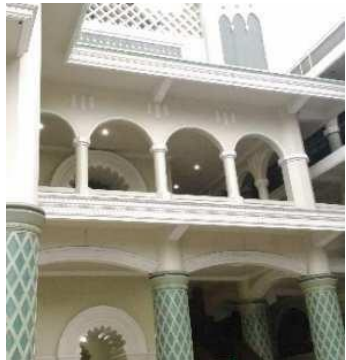

Circular, curly, and cornered Arch Geometrical ornaments

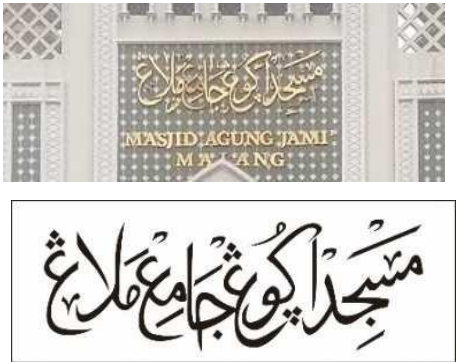

Ornament

calligraphy and details

Figure 2. The Façade of Jami' Great Mosque and The Constituting Architectural elements

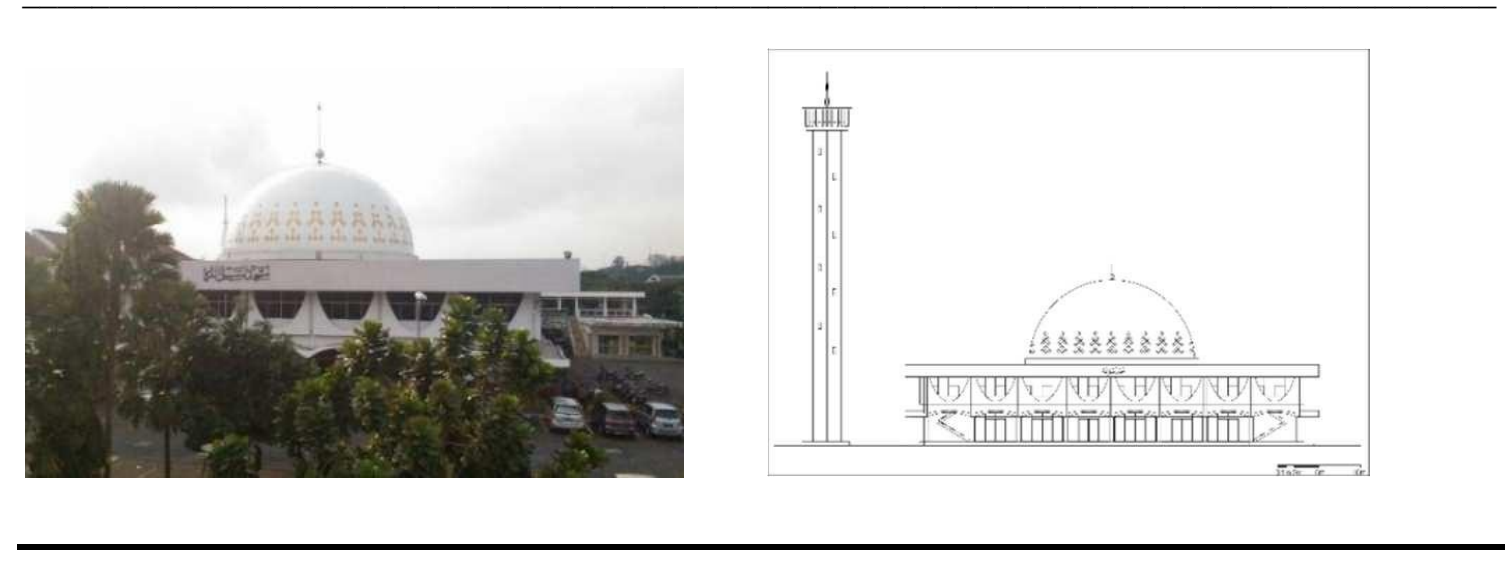

Figure 3. Photos and Façade Pictures of Sabilillah Mosque

\section{Nurul Muttaqin Mosque}

Nurul Muttaqin Mosque, established in 1938, is located on Aipda Satsui Tubun street, Malang, and included in the typology of a large mosque. The architectural elements which make up the architecture of Nurul Muttaqin Mosque are described in the following Figure 5 and 6. 


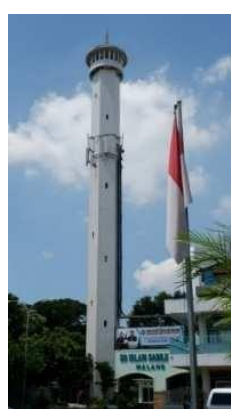

Single hexagonal minaret

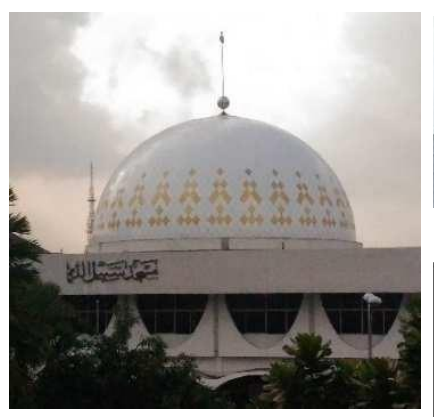

Ottoman dome (resembling mushroom) \& geometrical ornament (square)
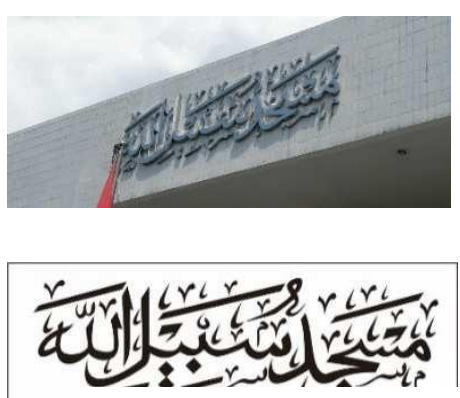

Calligraphy ornament (Khat Muhaqqaq) \& details

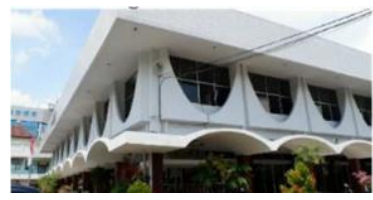

Circular Arch

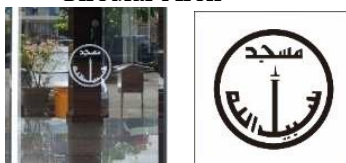

Calligraphy ornament (Square Kufi on the opening) \& detail

Figure 4. The Façade of Sabilillah Mosque and the Constituting Architectural Elements
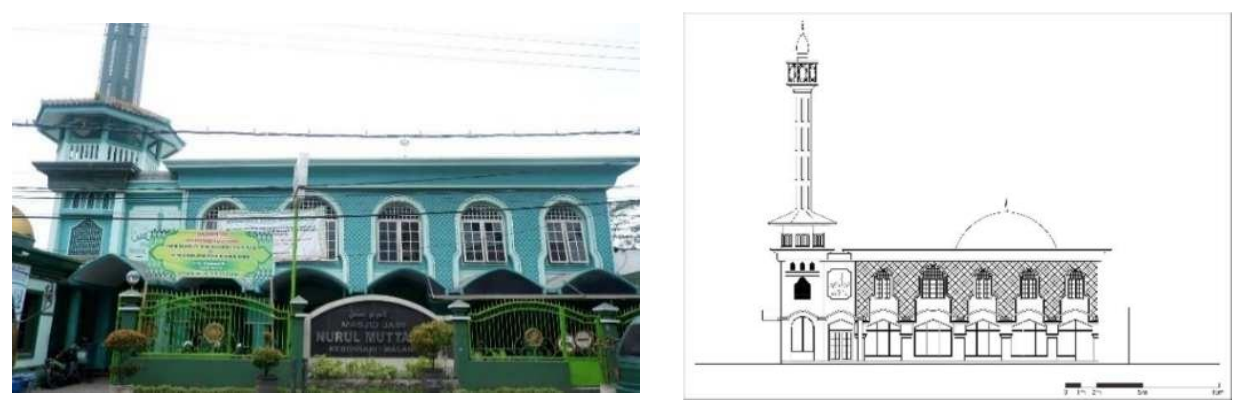

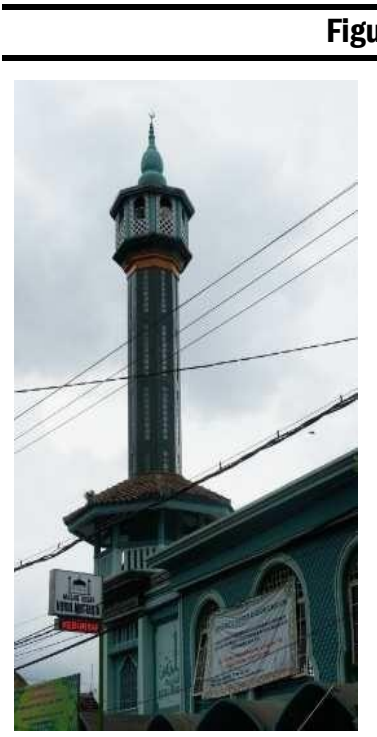

Single octagon minaret

gure 5. Photos and Façade Pictures of Nurul Muttaqin Mosque

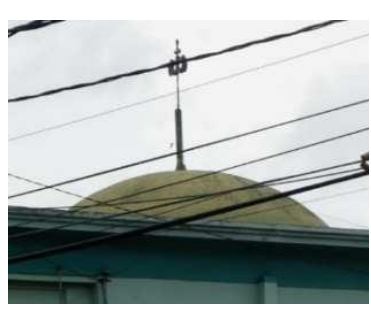

Ottoman dome \& mushroom-shaped dome

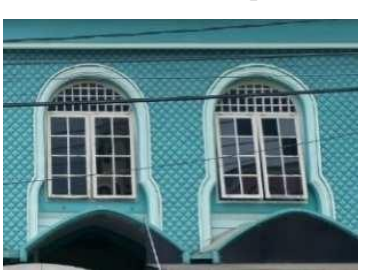

Circular Arch
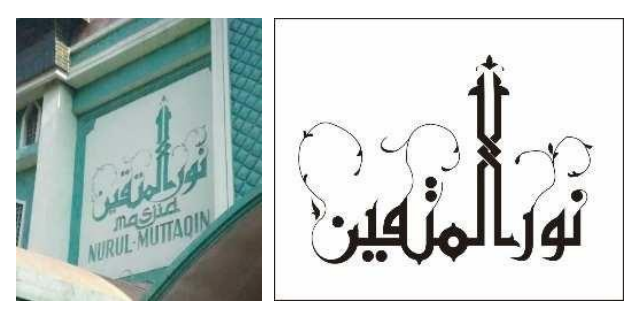

Calligraphy ornament (khat Eastern Kufic) \& detail
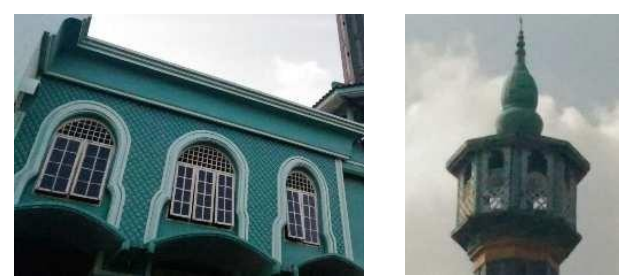

Geometrical Ornament (square)

Figure 6. The Façade of Nurul Muttaqin Mosque and the Constituting Architectural elements 


\section{Ahmad Yani Mosque}

Ahmad Yani Mosque is located at Kahuripan 12 Street in Malang and was established in 1962. This mosque is included in the typology of the Great mosque with a capacity of 1,200 worshipers. The architectural elements which make up the architecture of the Ahmad Yani Mosque are described in the following Figure 7 and 8.
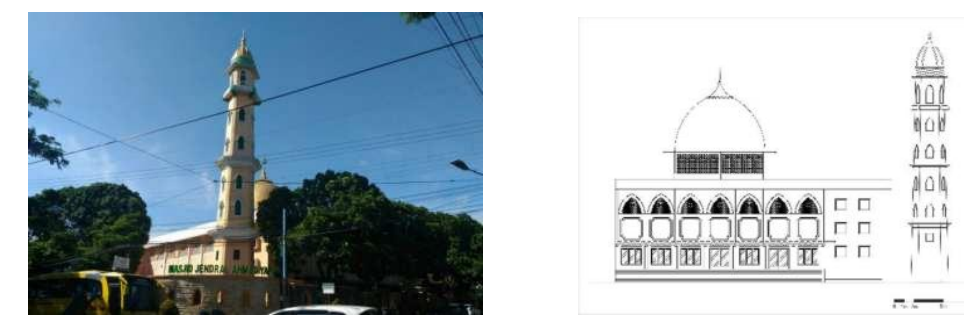

Figure 7. Photos and Façade Pictures of Ahmad Yani Mosque

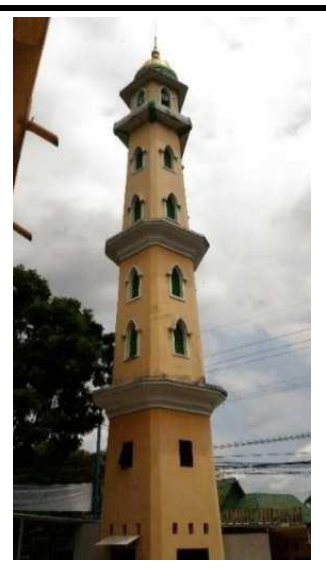

Single Pentagon Minaret

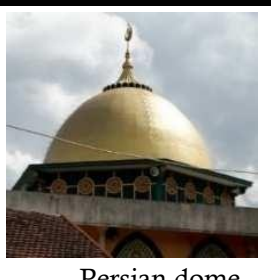

Persian dome

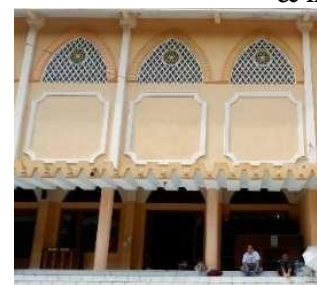

Cornered Arch

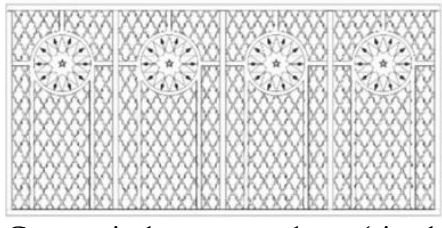

Geometrical ornament dome (circular $\&$ intricate) on the bottom of dome

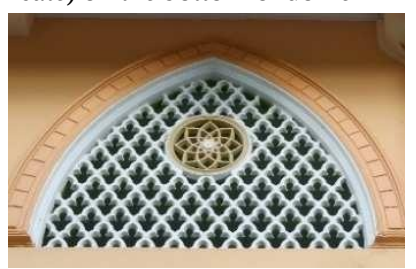

Floral ornament

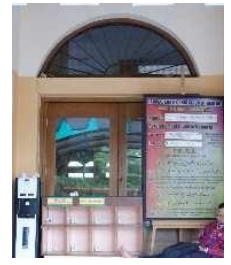

Circular Arch

Figure 8. The Façade of Ahmad Yani Mosque and the Constituting Architectural elements

\section{Manarul Huda Mosque}

Manarul Huda Mosque was founded in 1920 and located at Sumbersari 235A Street, Malang. The architectural elements which make up the architecture of the Manarul Huda Mosque are described in the following Figure 9 and 10.
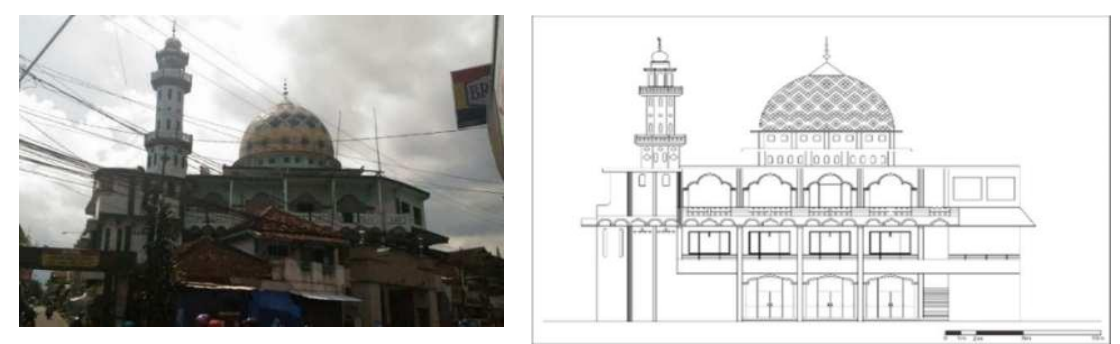

Figure 9. Photos and Façade Pictures of Manarul Huda Mosque 


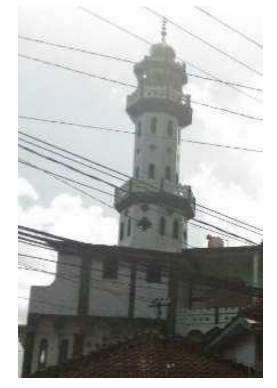

Single Octagonal Minaret

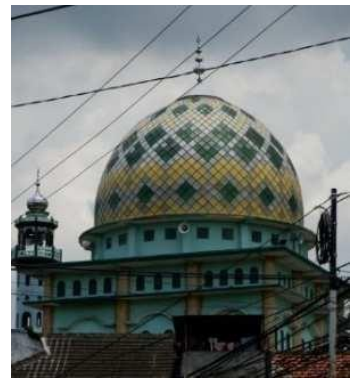

Persian dome (top-shaped) \& geometrical ornaments (square)
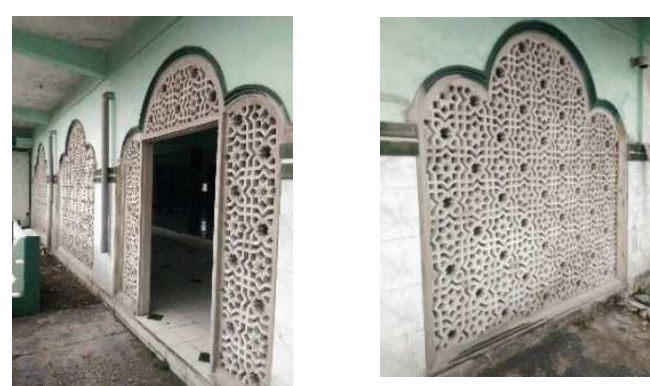

Curly arch \& geometrical ornament

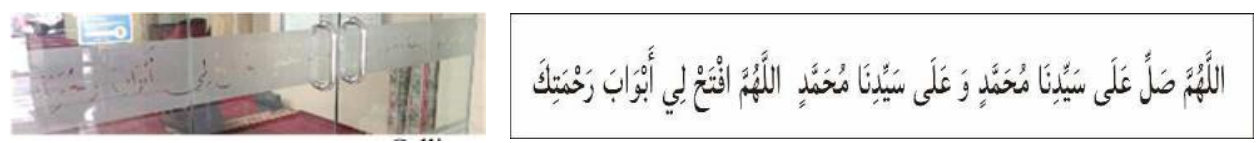

Calligraphy on the entrance and details

Figure 10. Architectural Elements of Manarul Huda Mosque

Based on the results of identification of mosques' architectural elements, the study identifies 5 different types of mosque architectural elements, hereinafter referred to as the level and variation in each level. In addition, these were also referred to as attribute level (Table 2). The results of the identification of various architectural elements in Table 2 were then used to compile stimuli in the questionnaire that will be given to respondents. The stimulus was a combination of sub variables or attributes. In the process of preparing stimuli, 20 stimuli were obtained.

\section{Utility Level Analysis of Each Attribute}

The initial analysis stage of conjoint analysis is utility level analysis of each attribute to show the use of mosque architectural elements based on public preference on mosques. which denoted the research object. Utility estimate with the biggest and positive value was the level with the highest preference according to the respondents (Table 2).

The analysis table previously presented explains that public preference towards the architectural characteristics of the mosque in Malang comproses of Indo-Persian-style domes, pentagon-shaped minarets, the number of minarets as many as two, the circular arch shape, and the types of calligraphy.

Table 2. Factor Utility Value

\begin{tabular}{llll}
\hline & & Utilities & \\
\hline Attributes & Rate of Attribute & Utility Estimate & Std. Error \\
\hline Dome style & Persian & -.076 & .028 \\
& Ottoman & -.020 & .033 \\
& Indo-Persian & .096 & .033 \\
Minaret shape & Octagon & .027 & .028 \\
& Hexagon & -.081 & .033 \\
Number of minarets & Pentagon & .054 & .033 \\
& One & -.150 & .021 \\
Arch shape & Two & .150 & .021 \\
& Circular & .126 & .028 \\
\multirow{2}{*}{ Types of ornament } & Cornered & .076 & .033 \\
& Curly & -.202 & .033 \\
& Floral & -.046 & .028 \\
& Geometry & -.077 & .033 \\
\hline
\end{tabular}




\begin{tabular}{llll}
\hline & & Utilities & \\
\hline Attributes & Rate of Attribute & Utility Estimate & Std. Error \\
\hline & Calligraphy & .123 & .033 \\
(Constant) & & 3.178 & .026 \\
\hline
\end{tabular}

\section{Analysis of Relative Importance Value and Architectural Characteristics of Mosques}

The analysis of the importance of relative level aims to determine the relative importance of each element of mosque architecture, related to public preference as a result of the utility level analysis of each attribute. The results of the analysis of the importance of the relative level and the graph are shown as follows:

1. Calligraphy ornaments (Relative Importance Rate: 22.731)

Calligraphy ornaments are typical ornaments of Islamic culture. The beauty of the design does not only originate from the form, but also comes from the meaning embedded [9]. Calligraphy ornaments use hijaiyah letters (Arabic script) with the verses of Al-Qur'an and hadith written on them. Calligraphy ornaments at mosques in Malang city are generally made in the form of marker that reads the name of the mosque. Calligraphy is usually placed in strategic places, such as the main entrance of the mosque or the middle of the façade, making them the center of attention.

2. Circular arch (Relative Importance Rate: 22.232)

Circular arch has a semi-circular arch. In mosques in Malang city, circular arches can be live arches and dead arches. Live arches mean that the arches appear as they are without myriads of ornaments.

3. Pentagon-shaped Minaret (Relative Importance Rate: 18.645)

The pentagon-shaped minaret has barriers which divide the minaret into sections. The conical shape of the minaret gets smaller upwards without wide balconies, both in the middle and the top of the minaret.

4. Indo-Persian style dome (Relative Importance Rate: 18.377)

Indo-Persian dome originates from Mughal or Indian regions. Indo-Persian dome is shaped like an onion with a shrinking dome neck. The Indo-Persian dome, which is adopted in the studied mosques, is compounded and also applied on the top part of the minaret.

5. Two-Minaret Design (Relative Importance Rate: 18.015)

Two minarets support symmetrical balance on building facades. A mosque with two minarets is often found in Iran. Minarets are usually located in front of the building or the main gate to the mosque.

The five elements of mosque architecture which shape the architectural characteristics of the city and become public preference can be summarized in the following schematic drawings (Figure 11.)

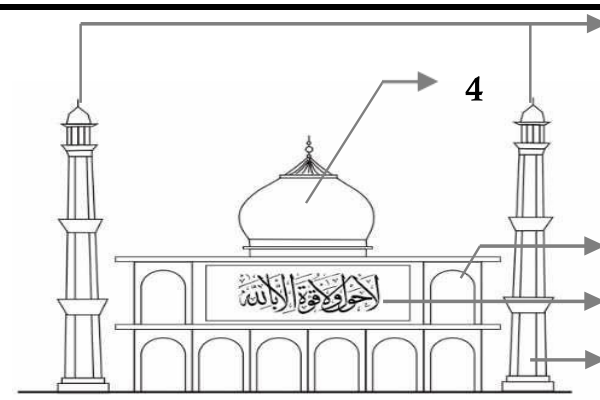
Description:
1: Calligraphy ornament
2: Circular arch
2
3: Pentagonal minaret
1 4: Indo-Persian dome
3
5: Double minarets

Figure 11. Scheme of Mosque Architectural Designs based on Public Preference in Malang City 


\section{CONCLUSION}

Architecture does not have a prototype or benchmark for each element of its architecture. The elements of mosque architecture are created because of the functional needs which support Muslim worship activities. Along with the development and spread of Islamic teachings in various regions, these elements are also developed in each region. This, as a corollary, makes mosque architecture evolves to involving various elements based on the local culture where the mosque is located. The mosque's architectural elements are characterized universally using domes, minarets, arches and ornaments. Mosque architectures in Malang city, Jami' Great Mosque of Malang, Sabilillah Mosque, Nurul Muttaqin Mosque, Ahmad Yani Mosque, and Manarul Huda Mosque, have various architectural elements, which are germane to dome style, minaret shape, arch shape, and the type of ornament used. The identification of architectural elements of mosque facade in Malang city demosntrates that most dome styles consist of Indo-Persian, Ottoman, and Persian designs. The shape of the minaret consists of pentagon, hexagon, and octagon. The number of minarets is generally limited to one and two minarets. The arch form consists of three types, including angular, circular, and curly, while the types of ornaments include floral design, geometry, and calligraphy. Based on the results of conjoint analysis, the study indicates that public preference towards the mosque's architectural characteristics in Malang varies from the highest to the lowest preferences. These include the type of ornament calligraphy, circular arch shape, minaret in the form of a pentagon, Indo-Persian style dome, and two-minaret design. The five characteristics of mosque architecture in Malang based on public preference can then be utilized as recommendations for mosque architectural design in the city for future construction so as to strengthen the local character and aesthetics.

\section{REFERENCES}

A'yun, Q. 2015. Transformasi Bentuk Fisik pada Tipologi Fasade Masjid Jami' Malang. EMARA Indonesian Journal of Architecture. 1 (2): 69-77.

Atmadjaja, J.S., \& Dewi, M. S. 1999. Estetika Bentuk. Jakarta: Gunadarma.

Fanani, A. 2009. Arsitektur Masjid. Yogyakarta: Bentang.

Laurens, Joyce Marcella. Arsitektur dan Perilaku Manusia. 2004. Jakarta: PT. Gramedia

Norman, D. A. 2004. Emotional Design Why We Love (or Hate) Everyday Things. New York: Basic Books

Pangarsa, G. W. 2010. Materialisme pada Masjid Nusantara. Malang: You Publish.

Santoso, S. 2015. Menguasai Statistik Multivariat. Jakarta: PT Elex Media Komputindo

Simas.kemenag.go.id diakses pada tanggal 13 Maret 2018

Sumalyo, Y. 2000. Arsitektur Mesjid dan Monumen Sejarah Muslim. Yogyakarta: Gadjah Mada University Press.

Sumintardja, D. 2003. Makna Menara dalam Arsitektur Islam. NALARS. 2 (1): 1-11.

Wardhono, U. P. 2009. Glosari Arsitektur. Yogyakarta: Penerbit Andi 